\title{
The Measurement of University Students' Intention to Use Blended Learning System through Technology Acceptance Model (TAM) and Theory of Planned Behavior (TPB) at Developed and Developing Regions: Lessons Learned from Taiwan and Indonesia
}

\author{
https://doi.org/10.3991/ijet.v15i09.11517 \\ Reny Nadlifatin $\left.{ }^{(}\right)$, Bobby Ardiansyahmiraja, Satria Fadil Persada \\ Institut Teknologi Sepuluh Nopember (ITS), Surabaya, Indonesia \\ renyeits.ac.id \\ Prawira Fajarindra Belgiawan \\ Institut Teknologi Bandung, Jawa Barata, Indonesia \\ A.A.N Perwira Redi \\ Universitas Pertamina, Jakarta, Indonesia \\ Shu-Chiang Lin \\ Texas Health and Science University, Texas, USA
}

\begin{abstract}
The present research exhibits the measurement of university students' behavioral intention in using a blended learning system. Two representative cases from a developed region and a developing region were assessed in the present measurement. Two well-known models, namely the Technology Acceptance Model (TAM) and the Theory of Planned Behaviour (TPB), were used as the measurement tools. A total of six hypotheses was tested. The result revealed the suitability of the TAM-TPB model in interpreting the sample students behavioral intentions' for both regions. The result also showed that for the Taiwanese data, five out of six hypotheses were accepted. For the Indonesian data, only four out of six hypotheses were exhibiting acceptable statistical measurement. Several recommendations, such as creating a more socialoriented blended learning system for developed countries was recommended. Utilizing the favourable feeling shown by developing countries students to create a better blended learning system, was also highly suggested to be considered for improvement.
\end{abstract}

Keywords-Blended Learning, TAM, TPB, Behavioral Intention, Developed Country, Developing Country 


\section{Introduction}

The current trends of technological advancements open many possibilities of learning methods. Digital learning, for example, is the utilization of technologies and digital tools to support the learning process [1]. Another learning method, which viewed to be the future of the teaching model, is called blended learning. Blended learning combines the best aspects of online learning and physical learning, creating an environment without the typical downside of online learning (e.g. requirement of online literacy and the minimal social interaction) and the typical downside of physical learning (e.g. the lack of content personalization and inefficient assessment method) [2-4]. Aside from the distinct technological advantages of blended learning, positive intention to use blended learning by students was also shown in many previous pieces of research, and understanding students' intention is an essential aspect of learning technology implementation [5-7]. These research papers showing perceived positive intention by students, however, were yet to consider another problem the educational world currently faces today: the concerning technological gap between developing and developed countries. This gap could even diminish the previously discussed advantages that emerged from the use of blended learning systems; in developing countries or communities which has limited access to Information and Communication Technology (ICT), traditional ways of delivering educational materials are seen to be a more practical solution [8]. In the context of understanding students' intention to use blended learning, this ICT gap could create different levels of ICT literacy and inturn, different perceived ease of use by students in economically different countries. Perceived ease of use is an aspect of technology acceptance that is proved to have a direct correlation with the intention to use a particular technology [9]. Different attitudes toward technology that are present in developed/developing countries could also explain students' intention in using a blended learning system [10]. Considering that blended learning usage intention could be affected by factors mentioned above, and other technology acceptance factors studied in previous researches [11, 12], this present research incorporates the developed/developing countries aspect and asks the question of: What are the factors affecting students in developed and developing countries to use blended learning?

To answer this question, we utilized some scientific models. The Theory of Acceptance Model (TAM) is one of the most prominent scientific models with many empirical tests shown the success of the TAM model; using it to investigate a broad range of IT-related cases [13]. The two main building blocks of TAM are the Perceived Ease of Use (PEOU) and Perceived Usefulness (PU); these two variables are suggested to be significant determinants of IT usage [14]. This advantage of TAM, however, could be improved by integrating it with other models such as the Theory of Planned Behavior (TPB) model. This integration between TAM and TPB is also showing successes in past researches $[15,16]$. Thus, the hypotheses asked in this present research will be based on TAM and TPB's variables, and will be explained in detail in the next section of the literature review. The third section of this article discusses the research methodology used in the present research, following that, result 
and analysis were discussed in the fourth section. Finally, a conclusion is presented in the last section, summarising the paper.

\section{$2 \quad$ Literature Review}

\subsection{Blended learning}

Different than most of the technology-enhanced learning that emphasizes students autonomy in learning (similar to m-learning) [12], blended learning has a more 'formal' aspect to it; blended learning is an education program where students learn partly from digital and online media [17]. Blended learning has proved to be successful in past empirical researches; the main reason is how blended learning has a more collaborative environment and the sense of learning autonomy that aroused students to learn better $[18,19]$. Soon, as technology advances, new types of media will be blended into the traditional learning method, thus creating a new blended learning environment [20]. This integration of new media types could be the future of blended learning.

\section{$2.2 \quad$ TAM and TPB}

Both the Technology Acceptance Model (TAM) and the Theory of Planned Behavior (TPB) has been used frequently as a tool to understand different factors influencing behavioral intentions in many pieces of research related to IT adoption and other unlimited range of subjects [21-23]. TPB works by investigating three main variables that are attitude, subjective norm, and perceived behavioral control. These variables inside the TPB framework could give researchers insights on which factors influence one's behavioral intention the most $[24,25]$. TAM works in the same way, except for the different factors incorporated to extract the behavioral intention. TAM uses only two variables in its model: the PU and PEOU [26]. The combination of TAM and TPB is present in many previous research papers, researchers, however, have different views on how to integrate the TAM and TPB models. One particular research uses all five factors from TAM and TPB and correlates it to behavioral intention [27]. Others see the Attitude factor in TPB as a factor that could be linked directly with TAM factors [16, 28, 29], generating a research framework (model and hypotheses) shown in Fig.1. The present research adopted this approach because it is a more common and reliable integration approach. A deeper understanding regarding the different factors affecting students' intention to use blended learning is also the reason to integrate the TAM and TPB frameworks.

Thus, our hypotheses are as follows:

H1: Perceived Ease of Use (PEOU) has a significant positive relationship to the Perceived Usefulness (PU) to use blended learning.

H2: Perceived Ease of Use (PEOU) has a significant positive relationship to the Attitude (AT) to use blended learning 
H3: Perceived Usefulness (PU) has a significant positive relationship to the Attitude (AT) to use blended learning

H4: Attitude (AT) has a significant positive relationship to the Behavior Intention (BI) to use blended learning

H5: Subjective norms (SN) has a significant positive relationship to the Behavior Intention (BI) to use blended learning

H6: Perceived Behavior Control (PBC) has a significant positive relationship to the Behavior Intention (BI) to use blended learning

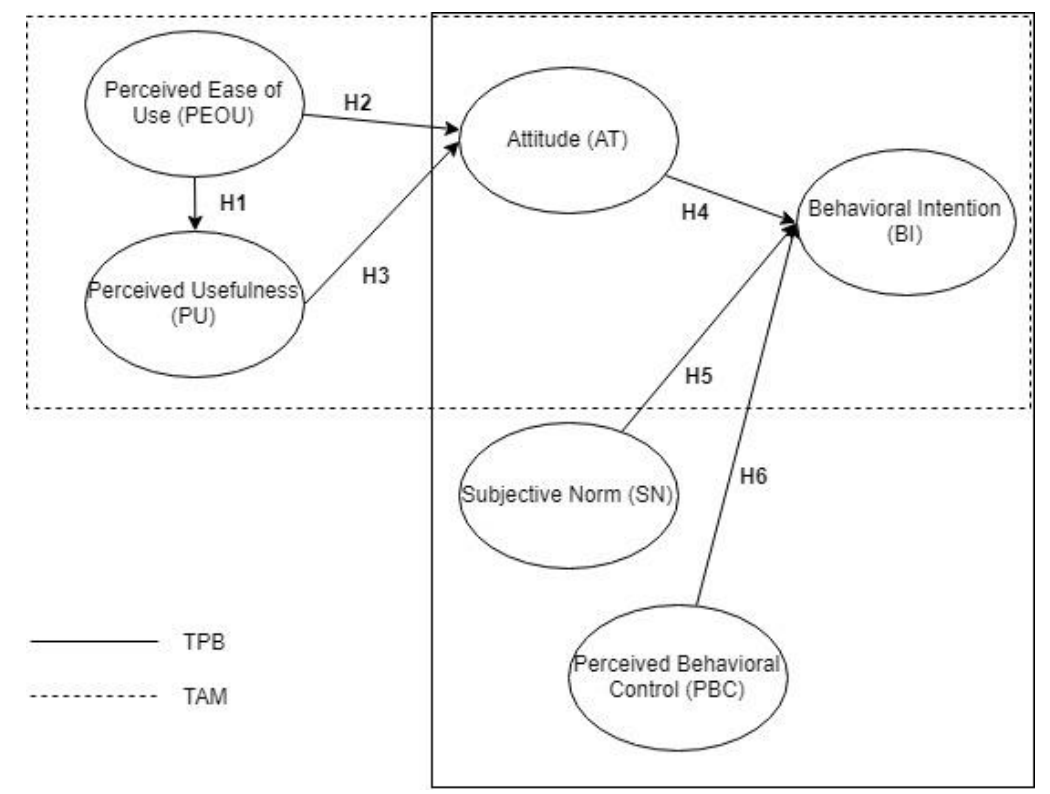

Fig. 1. Research Framework and Hypotheses

\section{$3 \quad$ Methodology}

\subsection{Instrument development}

We used Taiwan and Indonesia as case studies, with Taiwan representing developed countries and Indonesia representing developing countries [30]. In each country, we deployed a survey questionnaire to gather the needed data for our model. A purposive sampling method was used; the main criteria for our respondents were their blended learning exposure. The surveys in both countries examine TAM and TPB factors, which are Perceived Ease of Use (PEOU), Perceived Usefulness, Attitude (AT), Subjective Norm (SN), Perceived Behavioural Control (PBC), and Behavioural Intention (BI). Each factor measurement scale uses a Likert-scale (5-points), ranging from "Strongly disagree" to "Strongly agree" A total of 21 questionnaire items were asked. The present research was a multi-year project, data collections were conducted 
on a separate time. Taiwan questionnaire was distributed from July 2013 to December 2013 and the Indonesia questionnaire was distributed from September 2018 to November 2018. Table 1 presents a list of questions used in this research.

Table 1. The Present Research List of Questions

\begin{tabular}{|l|l|}
\hline \multicolumn{1}{|c|}{ Questionnaire Items } & Variables \\
\hline I think that blended learning system is easy to use & PEOU1 \\
\hline Blended learning system' study methods are easy to understand & PEOU2 \\
\hline My interaction with blended learning system was clear and understandable & PEOU3 \\
\hline I think blended learning system is useful for my studies & PU1 \\
\hline Blended learning system improves my course performance & PU2 \\
\hline I agree with the idea of using blended learning system for my course work & AT1 \\
\hline I believe it is a good idea to use this blended learning system for my course work & AT2 \\
\hline People who are important to me would think that I should use a blended learning system & SN1 \\
\hline People who influence me would think that I should use a blended learning system & SN2 \\
\hline I have sufficient control to make a decision to use the blended learning system & PBC1 \\
\hline Using a blended learning system was entirely within my control & PBC2 \\
\hline I have resources, knowledge and ability to use the blended learning system & PBC3 \\
\hline I intend to utilize a blended learning system during the semester & BI1 \\
\hline I will continue to use the blended learning system. & BI2 \\
\hline
\end{tabular}

\subsection{Measurement techniques for data and model}

To ensure the quality of the proposed model, this study firstly tested several aspects of the data and the model. The tests or the measurements in order to determine the reliability of the data involves the use of Cronbach $\alpha$ and composite reliability (CR), the minimum value for both measures is 0.7 . The same value of 0.7 was also used to test the factor loading, the correlation measure between an item of the questionnaire and a latent construct. To measure the convergent data validity, AVE measure was used with a minimum value of 0.5. For the model, several most reliable model-fit tests were used; this includes GFI, CFI, and AGFI. GFI requires a minimum value of 0.9 , both CFI and AGFI accept value higher than 0.8. Following these tests, the hypotheses generated from the model were tested using the Structural Equation Modeling (SEM). SEM has the ability to assess various complex factors in relation to a particular model, in this case, the TAM-TPB model. SEM can estimate and verify these factors, causal relationship between variables could also be analyzed at the same time [31].

\section{$4 \quad$ Result and Analysis}

\subsection{Data analysis}

In this sub-section, we present the various result of the measurement discussed in the third section. A total of 167 respondents participated in the Taiwanese questionnaire and 150 respondents for the Indonesian questionnaire. Table 2 and Table 3 
shows the result of data reliability and convergent validity of the Taiwanese and Indonesian data.

Table 2. Taiwanese Data Reliability and Convergent Validity

\begin{tabular}{|c|c|c|c|c|c|}
\hline Factor & Item & $\begin{array}{c}\text { Cronbach's } \alpha(>0.7) \\
{[32]}\end{array}$ & $\begin{array}{c}\text { Factor Loadings ( }>\text { 0.6) } \\
{[33-35]}\end{array}$ & $\begin{array}{c}\text { Composite Reliability } \\
(>\mathbf{0 . 7}) \\
{[\mathbf{3 6}]} \\
\end{array}$ & $\begin{array}{c}\text { AVE } \\
(>0,5) \\
{[37]}\end{array}$ \\
\hline PEOU & $\begin{array}{l}\text { PEOU1 } \\
\text { PEOU2 } \\
\text { PEOU3 } \\
\end{array}$ & 0.86 & $\begin{array}{l}0.85 \\
0.87 \\
0.75 \\
\end{array}$ & 0.86 & 0.68 \\
\hline PU & $\begin{array}{l}\text { PU1 } \\
\text { PU2 }\end{array}$ & 0.72 & $\begin{array}{l}0.74 \\
0.78\end{array}$ & 0.73 & 0.58 \\
\hline AT & $\begin{array}{l}\text { AT1 } \\
\text { AT2 }\end{array}$ & 0.90 & $\begin{array}{l}0.90 \\
0.89\end{array}$ & 0.89 & 0.80 \\
\hline SN & $\begin{array}{l}\mathrm{SN} 1 \\
\mathrm{SN} 2\end{array}$ & 0.86 & $\begin{array}{l}0.83 \\
0.96 \\
\end{array}$ & 0.89 & 0.81 \\
\hline $\mathrm{PBC}$ & $\begin{array}{l}\mathrm{PBC} 1 \\
\mathrm{PBC} 2 \\
\mathrm{PBC} 3\end{array}$ & 0.89 & $\begin{array}{l}0.79 \\
0.86 \\
0.90\end{array}$ & 0.89 & 0.72 \\
\hline BI & $\begin{array}{l}\text { BI1 } \\
\text { BI2 }\end{array}$ & 0.82 & $\begin{array}{l}0.85 \\
0.76 \\
\end{array}$ & 0.79 & 0.65 \\
\hline
\end{tabular}

Table 3. Indonesian Data Reliability and Convergent Validity

\begin{tabular}{|c|c|c|c|c|c|}
\hline Factor & Item & $\begin{array}{c}\text { Cronbach's } \alpha(>0.7) \\
{[32]}\end{array}$ & $\begin{array}{c}\text { Factor Loadings (>0.6) } \\
{[\text { 33-35] }}\end{array}$ & $\begin{array}{c}\text { Composite Reliability } \\
(>0.7) \\
{[36]}\end{array}$ & $\begin{array}{c}\text { AVE } \\
(>0,5) \\
{[37]}\end{array}$ \\
\hline PEOU & $\begin{array}{l}\text { PEOU1 } \\
\text { PEOU2 } \\
\text { PEOU3 }\end{array}$ & 0.71 & $\begin{array}{l}0.75 \\
0.88 \\
0.80\end{array}$ & 0.85 & 0.66 \\
\hline PU & $\begin{array}{l}\text { PU1 } \\
\text { PU2 }\end{array}$ & 0.85 & $\begin{array}{l}0.79 \\
0.71\end{array}$ & 0.72 & 0.56 \\
\hline AT & $\begin{array}{l}\text { AT1 } \\
\text { AT2 }\end{array}$ & 0.71 & $\begin{array}{l}0.78 \\
0.85 \\
\end{array}$ & 0.80 & 0.67 \\
\hline $\mathrm{SN}$ & $\begin{array}{l}\text { SN1 } \\
\text { SN2 }\end{array}$ & 0.87 & $\begin{array}{l}0.91 \\
0.86\end{array}$ & 0.88 & 0.78 \\
\hline $\mathrm{PBC}$ & $\begin{array}{l}\mathrm{PBC} 1 \\
\mathrm{PBC} 2 \\
\mathrm{PBC} 3\end{array}$ & 0.78 & $\begin{array}{l}0.72 \\
0.67 \\
0.83 \\
\end{array}$ & 0.79 & 0.55 \\
\hline BI & $\begin{array}{l}\mathrm{BI} 1 \\
\mathrm{BI} 2\end{array}$ & 0.84 & $\begin{array}{l}0.82 \\
0.88\end{array}$ & 0.84 & 0.72 \\
\hline
\end{tabular}

The recommended minimum value for each reliability test and convergent validity is shown in the table. Every item in the final model has surpassed those values: all the Cronbach's $\alpha$ for every factor in both countries even are higher than 0.7 , only one item that has factor loading under than 0.7 which still exceeded the minimum required value for factor loading, every factor also surpassed the minimum value for the composite reliability and Average Variance Extracted (AVE). The following values that will be presented are the values from model-fit tests; these tests are required in order to understand the degree of how the model fits the data. In the current model, mini- 
mum values for fit indices are set previously in the 3.3 sub-section. Table 4 shows the result of the model fit tests.

Table 4. Model Fit Results

\begin{tabular}{|l|c|c|c|}
\hline Model fit parameters & Taiwanese Model Result & $\begin{array}{c}\text { Indonesian Model } \\
\text { Result }\end{array}$ & Minimum Value \\
\hline GFI & 0.88 & 0.88 & $0.80[36]$ \\
\hline AGFI & 0.81 & 0.82 & $0.80[38]$ \\
\hline CFI & 0.92 & 0.91 & $0.90[39]$ \\
\hline IFI & 0.92 & 0.91 & $0.90[40]$ \\
\hline
\end{tabular}

As shown in Table 4, all the model fit indices for both countries have the required minimum values to be considered as good model fits, though the Indonesian model shows relatively better model fit indices values compared to the Taiwanese models. After evaluating the measurements of the data and the model, hypotheses then could be tested. Figure 2 shows the final SEM result for both models, and aside from the direct correlation estimates, the figure also shows the significances for each correlation path.

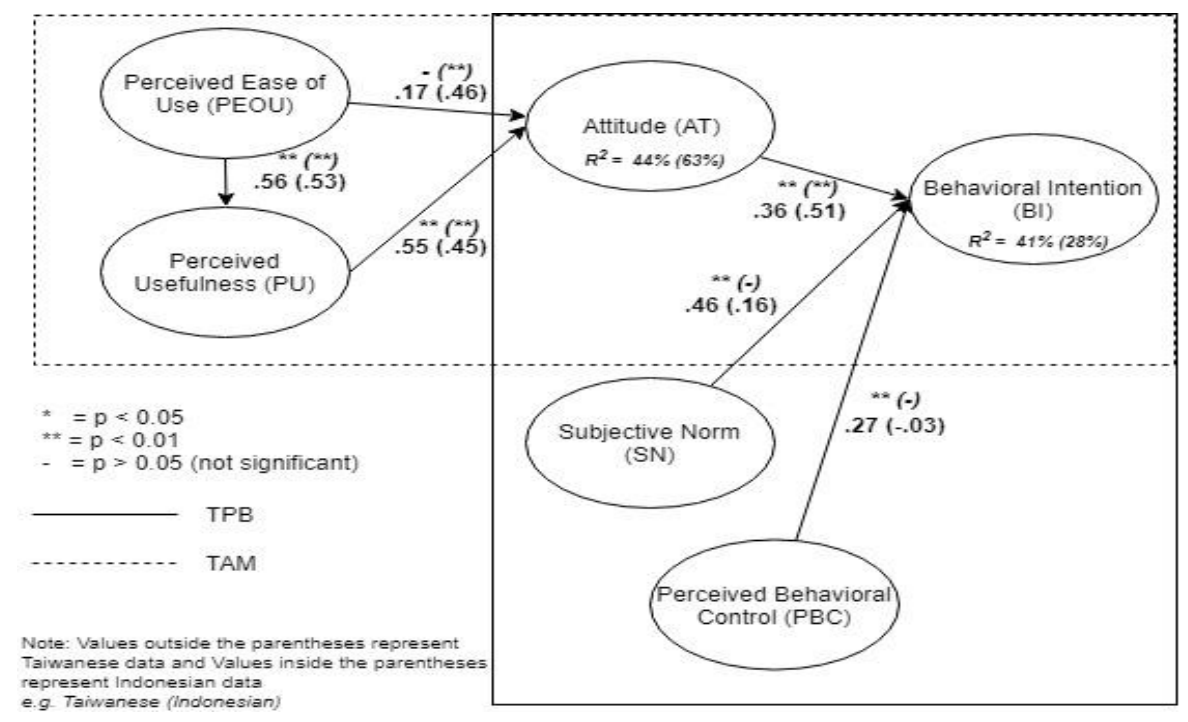

Fig. 2. Result of Both Models

The correlation significances are generated by using bootstrap, with a thousand sample and the Bias-corrected Confidence interval of 95. The Maximum Likelihood (ML) parameter was used for this bootstrap. As shown in the figure, some paths have an insignificant correlation; this brings us to the acceptance or the rejection of our proposed hypotheses. The result for the Taiwanese model shows that only one path has an insignificant correlation, the PEOU $\rightarrow$ AT path. For the Indonesian model, two paths were proven to have an insignificant correlation, the $\mathrm{SN} \rightarrow \mathrm{BI}$ path, and the 
$\mathrm{PBC} \rightarrow \mathrm{BI}$ path. Paths with insignificant correlation translated to the rejection of its hypotheses, H1 for the Taiwanese model was rejected, and H5 and H6 for the Indonesian model were rejected. The rest of the hypotheses are supported, and all of them show a positive correlation as shown in Table 5. The difference between the result of both countries can be triggered by how a developed country has many different fundamental aspects, views, and infrastructure towards blended learning. It can be interpreted that students from a developed country, which already has adequate infrastructure and mature blended learning system consider non-technical aspects more than developing countries students. Further explanation and how these numbers could be used in practical settings are detailed in the following subsection.

Table 5. Hypothesis Summary

\begin{tabular}{|c|c|c|l|}
\hline Hypothesis & Taiwanese Measurement & Indonesian Measurement & \multicolumn{1}{|c|}{ Note } \\
\hline H1 & 0.56 & 0.53 & Accepted \\
\hline H2 & 0.17 & 0.46 & $\begin{array}{l}\text { H2 Taiwan is rejected due } \\
\text { to insignificant value }\end{array}$ \\
\hline H3 & 0.55 & 0.45 & Accepted \\
\hline H4 & 0.36 & 0.51 & Accepted \\
\hline H5 & 0.46 & 0.16 & $\begin{array}{l}\text { H5 Indonesia is rejected } \\
\text { due to insignificant value }\end{array}$ \\
\hline H6 & 0.27 & -0.03 & $\begin{array}{l}\text { H6 Indonesia is rejected } \\
\text { due to insignificant value }\end{array}$ \\
\hline
\end{tabular}

\subsection{Theoretical implication}

This research contributes to the existing literature regarding modern learning technology. The TAM-TPB model used in this research showed considerable Squared Multiple Correlation (SMC) which is the indicator for how much the Behavioral Intention is represented by the factors used; Taiwan's data has the value of $41.2 \%$ SMC and Indonesia's has the value of $28.1 \%$. However, the remaining factors outside the TAM-TPB model should also be explored; other behavioral frameworks could be used to have a better understanding of blended learning. In the Indonesian data, another theoretical implication is also appearing. With $\mathrm{H} 5$ and $\mathrm{H} 6$ being rejected, essentially only the TAM model was used; and it showed a high positive correlation for each path. Future research should also consider the technical aspect of blended learning: the contents, curriculum, and facilities in order to assess the subject more comprehensively.

\subsection{Managerial interpretation}

Using SEM, its statistical methods, and employing the TAM-TPB combination model, results were presented in the previous sections; this subsection will focus on the managerial aspect of the results. In the Taiwanese data, Subjective Norm (SN) revealed to have the highest positive correlation to Behavioral Intention (BI), with the estimate $(\beta)$ value of 0.46 and the significance (p-value) of 0.002 . Revealing that 
developed nation students value their peers' opinions on blended learning greatly. This finding is consistent with a previous research piece [41]. Managements in the educational institutions of developed countries could use these findings and creates a more social-oriented blended learning. Another high value of positive correlation also shown in the PEOU $\rightarrow$ PU $(\beta=0.56$-value $=0.003)$ and the PU $\rightarrow$ AT $(\beta=0.55 p$ value $=0.003$ ) path. Showing that in the developed nation, having a favorable feeling toward blended learning is determined greatly by how they see its usefulness, and the perceived usefulness is also determined by how easy it is to use/adopt blended learning. The Indonesian data has the highest positive correlation from the AT $\rightarrow \mathrm{BI}$ $(\beta=0.51 \mathrm{p}$-value $=0.007)$, it can be interpreted that students in developing countries are ready to use blended learning because they already have a favorable feeling towards it. Educational stakeholders in Indonesia or other developing countries should consider blended learning as an important concept to be used more strategically in their curriculum. In a global context, both the developed and developing countries showed a positive correlation between AT and BI, meaning that the global students have already understood that blended learning is useful learning technology. Educators from all around the world should react to this accordingly, preparing all the needed resources to create a functioning blended learning system in their schools or universities.

\section{Conclusion}

The current research reveals the assessment of students' behavioral intention in perceiving blended learning. Two sample cases from the developed and developing regions are assessed in measurement analysis. Both famous TAM and TPB are used as the measurement tool. Several managerial implications such as developing a more social-oriented blended learning as well as understanding the favorable feeling on the readiness of blended learning are strongly suggested for improvement. Recommendation for the global educational word was also given. Finally, this research opens up a greater opportunity to explore the other factors that may influence the intention of students for future research. Analyzing the sample from other regions or countries may strengthen the insight in understanding the students in perceiving the use of blended learning.

\section{$6 \quad$ References}

[1] S. F. Persada, B. A. Miraja, and R. Nadlifatin, "Understanding the Generation Z Behavior on D-Learning: A Unified Theory of Acceptance and Use of Technology (UTAUT) Approach," International Journal of Emerging Technologies in Learning, vol. 14, no. 5, 2019. https://doi.org/10.3991/ijet.v14i05.9993

[2] M. Radović-Marković, "Advantages and disadvantages of e-learning in comparison to traditional forms of learning," OF THE UNIVERSITY OF PETROŞANI ECONOMICS , vol. 10, no. 2, pp. 289-298, 2010. 
[3] D. A. Cook, "Web-based learning: pros, cons and controversies," Clinical Medicine, vol. 7 , no. 1, pp. 37-42, 2007.

[4] J. Watson, "Blended Learning: The Convergence of Online and Face-to-Face Education. Promising Practices in Online Learning," North American Council for Online Learning, 2008.

[5] S. Y. Park, "An analysis of the technology acceptance model in understanding university students' behavioral intention to use e-learning," Educational technology \& society, vol. 12, no. 3, pp. 150-162, 2009.

[6] A. Padilla-MeléNdez, A. R. Del Aguila-Obra, and A. Garrido-Moreno, "Perceived playfulness, gender differences and technology acceptance model in a blended learning scenario," Computers \& Education, vol. 63, pp. 306-317, 2013. https://doi.org/10.1016/j.comp edu.2012.12.014

[7] N. Tselios, S. Daskalakis, and M. Papadopoulou, "Assessing the acceptance of a blended learning university course," Journal of Educational Technology \& Society, vol. 14, no. 2, pp. 224-235, 2011.

[8] S. Gulati, "Technology-enhanced learning in developing nations: A review," The International Review of Research in Open and Distributed Learning, vol. 9, no. 1, 2008. https:// doi.org/10.19173/irrodl.v9i1.477

[9] F. D. Davis, "Perceived usefulness, perceived ease of use, and user acceptance of information technology," MIS quarterly, pp. 319-340, 1989. https://doi.org/10.2307/249008

[10] M. Khan, S. Hossain, M. Hasan, and C. K. Clement, "Barriers to the introduction of ICT into education in developing countries: The example of Bangladesh," Online Submission, vol. 5, no. 2, pp. 61-80, 2012.

[11] A. Tarhini, K. Hone, X. Liu, and T. Tarhini, "Examining the moderating effect of individual-level cultural values on users' acceptance of E-learning in developing countries: a structural equation modeling of an extended technology acceptance model," Interactive Learning Environments, vol. 25, no. 3, pp. 306-328, 2017. https://doi.org/10.1080/104948 $\underline{20.2015 .1122635}$

[12] J. Cheon, S. Lee, S. M. Crooks, and J. Song, "An investigation of mobile learning readiness in higher education based on the theory of planned behavior," Computers \& education, vol. 59, no. 3, pp. 1054-1064, 2012. https://doi.org/10.1016/j.compedu.2012.04.015

[13] D. Gefen, E. Karahanna, and D. W. Straub, "Trust and TAM in online shopping: an integrated model," MIS quarterly, vol. 27, no. 1, pp. 51-90, 2003. https://doi.org/10.2307/300 $\underline{36519}$

[14] J.-W. Moon and Y.-G. Kim, "Extending the TAM for a World-Wide-Web context," Information \& management, vol. 38, no. 4, pp. 217-230, 2001. https://doi.org/10.1016/s03787206(00)00061-6

[15] M.-C. Lee, "Factors influencing the adoption of internet banking: An integration of TAM and TPB with perceived risk and perceived benefit," Electronic commerce research and applications, vol. 8, no. 3, pp. 130-141, 2009. https://doi.org/10.1016/j.elerap.2008.11.006

[16] M. A. Jani, G. I. P. Sari, R. C. H. Pribadi, R. Nadlifatin, and S. F. Persada, "An investigation of the influential factors on digital text voting for commercial competition: A case of Indonesia," Procedia Computer Science, vol. 72, pp. 285-291, 2015. https://doi.org/10.10 16/j.procs.2015.12.142

[17] W. Banyen, C. Viriyavejakul, and T. Ratanaolarn, "A blended learning model for learning achievement enhancement of Thai undergraduate students," International Journal of Emerging Technologies in Learning (iJET), vol. 11, no. 04, pp. 48-55, 2016. https://doi. org/10.3991/ijet.v11i04.5325 
[18] S. Wichadeeq, "A Development of the Blended Learning Model Using Edmodo for Maximizing Students' Oral Proficiency and Motivation," International Journal of Emerging Technologies in Learning, vol. 12, no. 2, 2017. https://doi.org/10.3991/ijet.v12i02.6324

[19] H. Liu, "An Analysis on Blended Learning Pattern Based on Blackboard Network Platform," International Journal of Emerging Technologies in Learning, vol. 11, no. 9, 2016.

[20] B. Güzer and H. Caner, "The past, present and future of blended learning: an in depth analysis of literature," Procedia-social and behavioral sciences, vol. 116, pp. 4596-4603, 2014. https://doi.org/10.1016/j.sbspro.2014.01.992

[21] J. L. R. Robledo, M. V. Arán, V. M. Sanchez, and M. Á. R. Molina, "The moderating role of gender on entrepreneurial intentions: A TPB perspective," Intangible Capital, vol. 11, no. 1, pp. 92-117, 2015. https://doi.org/10.3926/ic.557

[22] Y.-Y. Shih and C.-Y. Chen, "The study of behavioral intention for mobile commerce: via integrated model of TAM and TTF," Quality \& Quantity, vol. 47, no. 2, pp. 1009-1020, 2013. https://doi.org/10.1007/s11135-011-9579-x

[23] T. Ramayah, Y. M. Yusoff, N. Jamaludin, and A. Ibrahim, "Applying the theory of planned behavior (TPB) to predict internet tax filing intentions," International Journal of Management, vol. 26, no. 2, p. 272, 2009.

[24] S. Shah Alam and N. Mohamed Sayuti, "Applying the Theory of Planned Behavior (TPB) in halal food purchasing," International journal of Commerce and Management, vol. 21, no. 1, pp. 8-20, 2011. https://doi.org/10.1108/10569211111111676

[25] I. Ajzen, "The theory of planned behavior," Organizational behavior and human decision processes, vol. 50, no. 2, pp. 179-211, 1991. https://doi.org/10.1016/0749-5978(91)90020-t

[26] V. Venkatesh and F. D. Davis, "A theoretical extension of the technology acceptance model: Four longitudinal field studies," Management science, vol. 46, no. 2, pp. 186-204, 2000. https://doi.org/10.1287/mnsc.46.2.186.11926

[27] R. Safeena, H. Date, N. Hundewale, and A. Kammani, "Combination of TAM and TPB in internet banking adoption," International Journal of Computer Theory and Engineering, vol. 5, no. 1, p. 146, 2013. https://doi.org/10.7763/ijcte.2013.v5.665

[28] L. Wu and J.-L. Chen, "An extension of trust and TAM model with TPB in the initial adoption of on-line tax: an empirical study," International Journal of Human-Computer Studies, vol. 62, no. 6, pp. 784-808, 2005. https://doi.org/10.1016/j.ijhcs.2005.03.003

[29] H. Tseng, P. Tu, Y. Lee, and T. Wang, "A study of satellite navigation fleet management system usage in Taiwan with application of C-TAM-TPB model," Information Technology Journal, vol. 12, no. 1, pp. 15-27, 2013. https://doi.org/10.3923/itj.2013.15.27

[30] N. Fantom and U. Serajuddin, The World Bank's classification of countries by income. The World Bank, 2016.

[31] J. Ji and J. Gu, "Evaluation on the Effect of Service-Learning in EBusiness Professional Curriculum," International Journal of Emerging Technologies in Learning, vol. 14, no. 8, 2019.

[32] R. Nadlifatin, S.-C. Lin, Y. Rachmaniati, S. Persada, and M. Razif, "A pro-environmental reasoned action model for measuring citizens' intentions regarding ecolabel product usage," Sustainability, vol. 8, no. 11, p. 1165, 2016. https://doi.org/10.3390/su8111165

[33] J. F. Hair, M. Sarstedt, C. M. Ringle, and J. A. Mena, "An assessment of the use of partial least squares structural equation modeling in marketing research," Journal of the academy of marketing science, vol. 40, no. 3, pp. 414-433, 2012. https://doi.org/10.1007/s11747011-0261-6

[34] C. S. Lin, S. Wu, and R. J. Tsai, "Integrating perceived playfulness into expectationconfirmation model for web portal context," Information \& management, vol. 42, no. 5, pp. 683-693, 2005. https://doi.org/10.1016/j.im.2004.04.003 
[35] P. Kline, An easy guide to factor analysis. Routledge, 2014.

[36] S.-C. Lin, R. Nadlifatin, A. Amna, S. Persada, and M. Razif, "Investigating citizen behavior intention on mandatory and voluntary pro-environmental programs through a proenvironmental planned behavior model," Sustainability, vol. 9, no. 7, p. 1289, 2017. https ://doi.org/10.3390/su9071289

[37] S.-C. Lin, I. Mufidah, and S. Persada, "Safety-culture exploration in Taiwan's metal industries: Identifying the workers' background influence on safety climate," Sustainability, vol. 9, no. 11, p. 1965, 2017. https://doi.org/10.3390/su9111965

[38] G. Abedi, F. Rostami, and A. Nadi, "Analyzing the Dimensions of the Quality of Life in Hepatitis B Patientsusing Confirmatory Factor Analysis," Global journal of health science, vol. 7, no. 7, p. 22, 2015. https://doi.org/10.5539/gjhs.v7n7p22

[39] C.-L. Hsu and J. C.-C. Lin, "Acceptance of blog usage: The roles of technology acceptance, social influence and knowledge sharing motivation," Information \& management, vol. 45, no. 1, pp. 65-74, 2008. https://doi.org/10.1016/j.im.2007.11.001

[40] M. Siponen, M. A. Mahmood, and S. Pahnila, "Employees' adherence to information security policies: An exploratory field study," Information \& management, vol. 51, no. 2, pp. 217-224, 2014. https://doi.org/10.1016/j.im.2013.08.006

[41] A. Knabe, "Applying Ajzen's theory of planned behavior to a study of online course adoption in public relations education," 2012.

\section{Authors}

Reny Nadlifatin, Ph.D (Reny) studies focused on technology acceptance models, specifically on behavior towards information technology.

Bobby Ardiansyahmiraja (Bobby) is currently studying business management for a bachelor degree in the Department of Business Management, Institut Teknologi Sepuluh Nopember (ITS). Bobby's main research interest is in the technology and human resources area.

Satria Fadil Persada, Ph.D (Satria) research interest is studying the behavior of person's in the perspective of consumers and organization. Satria' research interest is also related to pro-environmental behavior.

Prawira Fajarindra Belgiawan, Ph.D (Fajar) research interest is in studying whether people's decision can actually be influenced by their significant others. Fajar's other research interest is in digital disruption.

A.A.N.Perwira Redi, Ph.D (Redi) research interest is in the field of industrial management.

Shu-Chiang Lin, Ph.D (Lin) is currently serve as the Vice President of Academics and the Director of the College of Business Science at Texas Health and Science University.

Article submitted 2019-08-14. Resubmitted 2019-12-05. Final acceptance 2019-12-06. Final version published as submitted by the authors. 